Pedagogik Jurnal Pendidikan, Maret 2015, Volume 10 Nomor 1, (17-31)

\title{
KONSELING INDIVIDU DALAM UPAYA PENANGGULANGAN DAMPAK PERSELINGKUHAN DALAM PERNIKAHAN
}

\author{
Oleh : Dina Fariza Tryani Syarif *
}

\begin{abstract}
Abstrak
Penelitian ini bertujuan untuk memberikan gambaran dan informasi bagi setiap pasangan yang menikah agar dapat lebih memahami sebuah kesetiaan dalam pernikahan dan mengetahui tahapan konseling individu untuk mengatasai perasaan bersalah karena telah berselingkuh.

Metode penelitian yang dilakukan adalah kualitatif dengan pendekatan studi kasus. Pengambilan data dilakukan dengan wawancara semi terstruktur.

Hasil penelitian menunjukan proses konseling yang menggunakan pendekatan gestalt yang menekankan pada peran persaaan dalam mempengaruhi prilaku dan potensi manusia untuk mampu memahami dan mengarahkan dirinya sendiri. Semua kejadian dikembalikan kepada diri subjek, meyakinkan bahwa subjek memiliki kemampuan untuk mengatasi permasalahannya, hanya saja semua hal harus disadari oleh diri subjek agar ia mampu secara sadar melakukan perubahan untuk dirinya sendiri.
\end{abstract}

\section{Kata Kunci : Perselingkuhan, Perkawinan}

\section{PENDAHULUAN}

Manusia merupakan makhluk sosial yang selalu berinteraksi dengan individu lainnya yang menjadikan manusia senantiasa membutuhkan orang lain, saling bersosialisasi, bertukar berbagai macam hal, hingga meneruskan keturunan. Hal ini merupakan wujud dari dorongan kebutuhan dasar manusia untuk dicintai dan dimiliki. Maslow (Feist \& Feist, 2008) menjelaskan bahwa kebutuhan manusia untuk dicintai dan dimiliki terwujud dalam beberapa hal, seperti dorongan untuk bersahabat, keinginan memiliki pasangan dan keturunan, dan kebutuhan untuk melekat pada sebuah keluarga, lingkungan bertetangga atau berbangsa. Lebih lanjut menjelaskan bahwa kebutuhan ini juga mencakup sejumlah aspek hubungan seksual dan hubungan interpersonal, seperti kebutuhan untuk memberi dan menerima cinta.

Kebutuhan-kebutuhan manusia

untuk memberi dan menerima cinta, memiliki pasangan dan keturunan, serta kelekatan pada sebuah keluarga dapat ditempuh melalui proses pernikahan. Pernikahan merupakan suatu kebutuhan individu dewasa untuk mencapai berbagai macam tujuan. Tujuan pernikahan diantaranya adalah mendapatkan keturunan, menyatukan dua keluarga, serta memenuhi kebutuhan biologis pelaku pernikahan yang bersangkutan. Herning (Aqmalia \& Fakhrurrozi, 2009) menjelaskan bahwa pernikahan merupakan suatu ikatan antara pria dan wanita yang kurang lebih permanen, ditentukan oleh kebudayaan dengan tujuan mendapatkan kebahagiaan.

Setiap orang yang memasuki hubungan pernikahan memiliki harapan masing-masing dalam pernikahannya. Individu berharap dapat memenuhi harapan-harapan tersebut melalui pernikahan yang dijalani. Keterpenuhan

\footnotetext{
* Dina Fariza Tryani Syarif, M.Psi Dosen FKIP Universitas Muhammadiyah Palangkaraya
} 
harapan dan kebutuhan dalam pernikahan menjadi sebuah standar untuk menilai tingkat kualitas hubungan pernikahan tersebut. Individu yang merasa kualitas pernikahannya sesuai dengan harapannya, akan merasakan kepuasan dalam pernikahan. Sebaliknya individu yang merasa kualitas pernikahannya belum sesuai dengan harapannya, cenderung tidak merasakan kepuasan dalam pernikahan.

Pernikahan yang sehat dan bahagia, masing-masing pasangan akan memperoleh dukungan emosional, rasa nyaman, pemenuhan kebutuhan seksual, serta memiliki teman bertukar pikiran yang amat menyenangkan. Banyak hasil penelitian yang menunjukan bahwa mereka yang bertahan dalam perkawinan menyatakan lebih bahagia dibandingkan mereka yang tidak memiiliki pasangan dan juga berumur lebih panjang (Gottman\&Silver, 2007). Pada saat mengalami permasalahan atau melewati masa-masa sulit, peran pasangan juga amat penting karena dapat mengurangi rasa sedih, menghindari dari perasaan putus asa, dan membantu proses pemulihan ke arah kondisi semula.

Di balik kebahagiaan dan kenyamanan yang diperoleh dari hubungan dengan pasangan, pernikahan juga dapat menjadi sumber yang stres yang luar biasa. Kegagalan pasangan untuk menyesuaikan diri dan memecahkan masalah-masalah secara efektif dapat memicu konflik yang berkepanjangan (Sarafino, 2006). Dalam jaman modern, tantangan pernikahan semakin berat berbeda dengan perkawinan tradisional yang member batasan jelas antara peran suami dengan perasaan istri, pembagian peran pada pernikahan modern sering kali tidak jelas. Saat ini banyak istri yang juga bekerja di luar rumah sehingga lebih menginginkan peran yang setara, yaitu suami terlibat aktif dalam pengasuhan anak-anak. Padahal banyak pihak suami yang belum siap dengan peran ganda tersebut (Gottman\&Silver, 2007).

Pasangan modern mendapatkan tantangan tambahan, selain dituntut untuk bekerja keras untuk bisa memenuhi standar hidup yang relatif tinggi sehingga waktu untuk bertemu dan berkomunikasi sangat terbatas. Waktu luang yang biasanya digunakan untuk berpergian dengan anakanak atau menghadiri berbagai acara keluarga. Karena itu begitu banyak tugas dan kewajiban yang harus dilakukan sehari-hari, tidak mengherankan bila hubungan dalam pernikahan sering mengalami gejolak.

Kondisi perkawinan yang tidak menyenangkan dan banyak harapan yang tidak terpenuhi, dapat memicu perselingkuhan. Hubungan yang intim dengan orang ketiga dapat bermula dari pertemanan biasa tetapi kemudian berlanjut semakin dalam ketika masing-masing membuka diri dan saling menceritakan masalah (Glass \& Staeheli, 2003). Perselingkuhan yang tidak diketahui oleh pasangan biasanya tidak memberikan dampak yang negatif. Bahkan mereka yang berselingkuh pengalaman-pengalaman yang menyenangkan sehingga merasa lebih bahagia. Namun ketika perselingkuhan terungkap, mulailah masa-masa sulit dalam perkawinan, baik bagi pasangan yang menjadi korban maupun pasangan yang berselingkuh ( Glass \& Staeheli, 2003; Subtonik \& Harris, 2005).

Di jaman modern sekarang ini perselingkuhan tidak hanya dilakukan oleh pihak suami tetapi Komisi Perlindungan Anak Indonesia (KPAI) mengungkap 9 kasus perceraian akibat perselingkuhan, 7 diantaranya dilakukan oleh ibu yang berselingkuh dengan pria lain berdasarkan

* Dina Fariza Tryani Syarif, M.Psi Dosen FKIP Universitas Muhammadiyah Palangkaraya 
hasil penelitian $40 \%$ istri di Jakarta dan kota besar lainnya melakukan selingkuh (Rimba, Kartini 2005).

Salah satu karakteristik kepuasan pernikahan menurut Klagsburg (Aqmalia \& Fakhrurrozi, 2009) adalah menikmati kebersamaan dengan pasangan. Karakteristik ini dapat terpenuhi ketika individu tinggal bersama dan menghabiskan waktu dengan pasangan. Dalam beberapa pernikahan, hal ini tidak dapat terpenuhi ketika individu tinggal terpisah dalam jarak yang jauh dengan pasangan. Hal ini menjadi salah satu penyebab kurangnya kepuasan dalam pernikahan karena kurangnya intensitas untuk memiliki waktu bersama serta kurang kedekatan.

Kepuasan pernikahan berkaitan dengan perasaan bahagia yang dirasakan oleh kedua individu dari pernikahan yang dijalani. Individu yang tidak merasakan kepuasan dalam pernikahan akan berupaya mencari kepuasan di luar pernikahannya. Liu (Olson, dkk, 2002) mengemukakan hasil penelitian yang telah menemukan bahwa orang-orang dengan jenis pekerjaan yang berada di luar rumah, jarang menghadiri kegiatan di tempat ibadah, serta orang-orang dengan kepuasan pernikahan yang rendah, adalah orang-orang yang beresiko untuk berselingkuh.

Perselingkuhan dalam rumah tangga menimbulkan dampak terhadap rumah tangga pelaku perselingkuhan sendiri. Dampak terhadap rumah tangga diantaranya kurangnya kepercayaan dari anggota keluarga kepada pihak yang melakukan perselingkuhan serta kehilangan keharmonisan. Hilangnya keharmonisan dalam rumah tangga pada akhirnya dapat berakibat pada perceraian. (Amato \& Rogers , 2007) mengatakan bahwa perselingkuhan merupakan penyebab yang paling banyak terdaftar sebagai penyebab perceraian. Studi yang dilakukan Amato dan Rogers terhadap lebih dari 2.000 orang yang telah menikah di Amerika untuk menguji pengaruh berbagai masalah dalam pernikahan terhadap perceraian, ditemukan bahwa hubungan seks di luar nikah memberikan dampak pada perceraian dua kali lebih besar dari masalah lainnya (Olson, dkk 2006).

Perselingkuhan terjadi disebabkan oleh berbagai macam faktor dan faktorfaktor tersebut berbeda pada setiap orang. Dampak yang ditimbulkan dari perselingkuhan juga berbeda antara satu orang dengan yang lain. (Hargave, 2008) dalam penelitiannya menjelaskan bahwa perselingkuhan juga menyebabkan hilangnya ketentraman dalam rumah tangga. Ketentraman yang dimaksud adalah hilangnya keharmonisan, kurangnya perhatian, serta terganggunya perkembangan jiwa anak.

Mengingat besarnya dampak yang diakibatkan perselingkuhan serta banyaknya angka perselingkuhan yang terjadi, maka faktor-faktor penyebab, dampak perselingkuhan dan bagaimana pemberian konseling terhadap si pelaku merupakan hal yang menarik untuk ditelaah lebih lanjut.

\section{METODE PENELITIAN}

Metode penelitian yang dilakukan adalah kualitatif dengan pendekatan studi kasus. Pengambilan data dilakukan dengan wawancara semi struktur. Pencapaian kredibilitas penelitian dilakukan dengan teknik triangulasi sumber melalaui wawancara dengan significant person dan membandingkan kedua data.

\section{Partisipan Penelitian}

Partisipan dalam penelitian ini adalah

* Dina Fariza Tryani Syarif, M.Psi Dosen FKIP Universitas Muhammadiyah Palangkaraya 
seorang wanita yang menjadi klien peneliti dalam permasalahan perselingkuhan. Karakteristik partisipan adalah sebagai berikut :

a. Seorang istri yang melakukan perselingkuhan.

b. Menjalani terapi untuk mengatasi masalah-masalah yang dihadapi sehubungan dengan perselingkuhan yang dilakukannya selama ini selama lebih dari enam bulan atau minimal sepuluh sesi pertemuan konseling.

c. Telah mengalami perubahan positif dalam kondisi emosi dan penyesuaian diri dalam kehidupan sehari-hari.

\section{Teknik Pengumpulan Data}

Dalam penelitian ini metode pengumpulan data adalah menggunakan teknik observasi dan wawancara. Hasil terapi dari konseling yang telah dilakukan.

\section{Prosedur Penelitian}

Pemilihan partisipan adalah didasarkan kesediaan partisipan yang merupakan klien peneliti untuk dijadikan partisipan penelitian. Kepada partisipan dijelaskan hal-hal berikut:

a. Tujuan penelitian

b. Proses penelitian yang akan dilakukan

c. Kerahasiaan identitas dalam penulisan penelitian

\section{HASIL DAN INTERVENSI}

1. Identitas Subjek

Tabel 1. Identitas Subjek

\begin{tabular}{ll}
\hline Usia & 33 tahun \\
\hline Pendidikan terakhir & Kuliah S1 \\
Pekerjaan & Wiraswasta \\
Tahun Pernikahan & 2012 \\
Usia Suami & 33 tahun \\
Pendidikan suami & Kuliah S 1 \\
Jumlah Anak & - \\
Lama Terapi & 8 bulan \\
Jumlah sesi & 9 sesi \\
\hline
\end{tabular}

\section{Gambaran Kehidupan Pernikahan}

Subjek dan suami telah menjalin hubungan yang cukup lama sebelum mereka memutuskan akhirnya untuk menikah. Dari awal masa pacaran sampai dengan awal pernikahan hubungan subjek dan suami berjalan dengan sangat baik dan saling menyayangi. Bahkan menurut subjek pada awal pernikahan perasaan sayang dan cinta semakin bertambah dibandingkan pada masa pacaran, tergambar suatu hubungan yang romantis dari cerita subjek atas hubungannya dengan suami. Subjek memiliki persepsi yang baik terhadap suaminya bahwa suaminya adalah laki-laki yang bertanggung jawab terhadap keluarga, sangat menyayangi keluarga dan seorang pekerja keras, dan suami menerima subjek apa adanya dengan baik dan selalu berusaha menyenangkan hati subjek.

Secara umum subjek merasa cocok dengan sifat-sifat yang dimiliki suaminya, subjek juga diberikan kebebasan oleh suami untuk menjalankan aktivitas dalam berkarier.

Dalam kehidupan sosial di luar pernikahannya subjek menyadari bahwa dirinya kurang memperkenalkan kehidupan sosialnya dengan suami. Dan suami juga memang tergambarkan tidak memperdulikan kehidupan sosial subjek terutama dalam lingkungan pekerjaan. Hal ini menyebabkan suami tidak terlalu banyak mengetahui lingkungan pergaulan subjek, dan subjek merasakan bahwa ia mendapatkan celah kebebasan diri pada sikap ketidak pedulian suami tehadap lingkungan sosialnya.

Ketidak puasan subjek terhadap kehidupan pernikahan di awali dengan rasa jenuh dengan kebersamaan mereka berdua yang menurut subjek selalu sama di setiap harinya. Dan karena ketidak pedulian masing-masing pihak atas kehidupan di luar

\footnotetext{
* Dina Fariza Tryani Syarif, M.Psi Dosen FKIP Universitas Muhammadiyah Palangkaraya
} 
pernikahan. Memang subjek dan suami telah saling mengenal sejak masa SMP dan telah menjalin hubungan pacaran sejak mereka sama-sama duduk di SMA. Jadi terkadang rasa jenuh dan bosan selalu datang dalam kehidupan subjek. oleh karena itu, subjek berusaha mengurangi rasa jenuh dengan mengikuti berbagai macam kegiatan selain kesibukannya di kantor. Suami juga tidak banyak mempermasalahkan hal tersebut, menurut cerita subjek suami menanggapi dengan positif mengenai kesibukan subjek, dan suami hanya akan SMS atau menelpon jika subjek belum pulang kerumah sampai dengan pukul 22.00 WIB. Dan jika subjek pulang terlambat suami tidak pernah menanyakan dari mana subjek dan kenapa pulang terlambat. Hal ini menurut subjek bukan karena suami tidak mempedulikan dirinya, namun dikarenakan suaminya sangat percaya dengan apa yang dilakukan subjek. Hal ini juga kemudian dilakukan subjek terhadap suaminya, dia jarang sekali menanyakan kemana suaminya pergi, dengan siapa dan jam berapa akan pulang ke rumah. Terkadang menurut subjek sering kali suaminya pulang ke rumah hampir subuh dan dia juga enggan menanyakan darimana saja suaminya, dan kenapa pulang subuh.

Dari gambaran kehidupan pernikahan subjek di atas diketahui bahwa pola komunikasi antara subjek dan suami kurang terjalin dengan baik, hal ini dikarenakan subjek dan suami sudah merasa saling mengenal sejak lama sehingga sudah menganggap saling mempercayai sehingga tidak perlu banyak bertanya tentang keberadaan masing-masing pihak.

Masalah dalam pernikahan dan cara penyelesaian

Subjek dan suami memiliki permasalahan ekonomi di dalam rumah tangga. Suami subjek terkadang lebih banyak bekerja di luar kota dan subjek disibukkan dengan pekerjaannya serta kegiatan keorganisasiannya. Sampai sekarang subjek dan suami belum menemukan cara penyelesaian permasalahan ini karena tuntutan ekonomi. Ada satu hal yang terkadang membuat subjek marah dengan suaminya ketika suaminya memberikan uang kepada orang tua tanpa sepengetahuan subjek. Hal ini menjadi suatu permasalahan karena subjek merasa meraka belum mapan dalam kehidupan ekonomi, subjek menganggap suaminya lebih mementingkan keluarganya sendiri dibandingkan diri subjek. Padahal dia juga ikut bekerja keras untuk menafkahi kehidupan rumah tangga mereka. Hal tersebut membuat subjek merasa tidak dihargai sebagai seorang istri karena sumi tidak memberitahukan dan tidak melibatkan dirinya dalam hal pengeluaran. Suami sering memberikan uang tanpa sepengetahuan subjek. Pada dasarnya subjek tidak berkeberatan kalau suami memberikan uang kepada orang tuanya, selama suami tidak berlebihan dan mengajak subjek untuk melakukan perundingan sebelumnya.

Permasalahan dalam rumah tangga subjek pada umumnya tidak melibatkan kekerasan fisik yang berat, terkadang subjek dan suami hanya saling "mendorong" dengan tidak terlalu keras dibeberapaa bagian tubuh misalnya punggung atau dada. Selain itu terkadang mereka juga saling mengumpat atau hanya saling diam. Penyelesaian permasalahan terkadang dilakukan dengan meminta maaf dan suami lebih sering mengalah namun terkadang keadaan membaik dengan sendirinya, dan secara umum tidak ada penyelesian masalah secara khusus yang

\footnotetext{
* Dina Fariza Tryani Syarif, M.Psi Dosen FKIP Universitas Muhammadiyah Palangkaraya
} 
dilakukan suami dan subjek.

Dari gambaran masalah dan penyelesaian masalah dalam kehidupan pernikahan subjek dan suami di atas diketahui apabila sedang menghadapi permasalahan terkadang subjek dan suami mengalami kesulitan dalam melakukan kontrol emosi sehingga terkadang saling menyakiti dengan saling melakukan kekerasan dalam rumah tangga baik secara fisik dan verbal walaupun dirasa dalam tingkat yang ringan. Namun tidak ada satu orangpun yang mau menyelesaikan permasalahan secara khusus. Masalah cenderung dianggap selesai dan dibiarkan begitu saja tanpa ada tindakan penyelesaian lebih lanjut.

\section{Alasan melakukan perselingkuhan}

Alasan subjek dalam melakukan perselingkuhan adalah kejenuhan dan merasa telah dibohongi suami ketika suami memberikan uang kepada orang tuanya secara diam-diam. Subjek mencari pelarian diri dengan mencari kesenangan untuk dirinya sendiri dengan jalan melakukan perselingkuhan. Menurutnya pasangan selingkuhnya lebih bisa memberikan waktu dan perhatian kepada dirinya dibandingkan suaminya. Perhatian yang diberikan pasangan selingkuh yaitu dengaan kata-kata mesra di setiap SMS atau telepon atau bahkan setiap mereka bertemu, hal ini membuat subjek merasa sangat diperhatikan.

Menurut significant person, alasan subjek melakukan perselingkuhan karena adanya ketertarikan secara seksual. Subjek menginginkan hal yang lain dari selama ini yang didapat dari suaminya. Seperti yang diketahui subjek dan suami jarang bertemu dikarenakan kesibukan masing-masing pihak, sehingga kebutuhan seksual sedikit kurang terpenuhi dalam intensitas yang tinggi. Kebutuhan inilah yang mendorong subjek melakukan perselingkuhan, selain itu ia juga mempunyai banyak kesempatan untuk melakukan hal tersebut karena suami jarang menanyakan tentang keberadaan diri subjek.

Perselingkuhan merupakan hal yang sudah pernah dilakukan subjek sejak sebelum menikah. Selama suami dan subjek masih masa berpacaran diketahui subjek telah melakukan selingkuh dengan beberapa orang laki-laki. Penyebab perselingkuhan dimungkinkan karena nilai yang diyakini subjek bahwa perselingkuhan bukanlah suatu masalah yang besar, semua orang bisa melakukannya baik laki-laki maupun perempuan. Subjek juga selalu membutuhkan kedekatan dengan lawan jenis, sehingga ketika bosan atau putus dengan pasangan yang satu dia akan mencari pasangan yang lain.

Subjek sudah pernah melakukan hubungan seksual di luar penikahan, hal ini juga dilakukan dengan suaminya sebelum menikah. Sehingga kemungkinan subjek sudah terbiasa melakukan hubungan seksual di luar pernikahan seperti ini.

\section{Pola Perselingkuhan}

Menurut subjek, perselingkuhan yang dilakukan hanya sebatas pacaran biasa dimana hanya melibatkan aktivitas seperti jalan-jalan, makan, dan berbincang. Subjek tidak memiliki harapan jangka panjang mengenai hubungannya ini dan hanya berupa pelarian saja.

Menurut significant person, perselingkuhan subjek tidak melibatkan perasaan. Hubungan yang dijalani subjek merupakan hubungan yang tidak serius, namun menurut significant person perselingkuhan subjek sudah sampai pada tahap keterlibatan aktivitas seksual.

Subjek sendiri tidak berniat 
mengacaukan pernikahannya dengan perselingkuhannnya oleh karena itu subjek juga berusaha untuk menjaga rahasia perselingkuhan agar hubungannya dengan suami tetap baik.

\section{Dampak perselingkuhan}

$\begin{array}{rrr}\text { Subjek } & \begin{array}{r}\text { merasakan } \\ \text { ketika }\end{array} & \text { kecemasan dan } \\ \text { ketakutan } & \text { melakukan }\end{array}$ perselingkuhan. Rasa takut yang dialami subjek bukan karena merasa bersalah, namun lebih pada perasaan ketakutan apabila hal ini akan diketahui oleh suami maupun keluarganya. Untuk itu subjek berusaha memberikan perhatian lebih kepada suaminya, agar suami tidak mencurigai perbuatannya. Subjek selalu merasa terancam apabila pasangan selingkuhnya tidak dapat menerima keadaan dirinya, dan terkesan membahayakan hubungannya dengan suami.

\section{Intervensi}

Penanganan terhadap kasus perselingkuhan ini adalah dengan melakukan terapi yang berdasarkan dari Psikologi Gestalt, yang dikembangkan oleh Frederick S. Pearl pada tahun (1894-1970).

Menurut Sudrajat, 2008 proses konseling dalam terapi ini mengikuti lima hal yang penting yaitu :

1. Fase I : Pemolaan (Patterning) dan pengawasan ( Control)

Pemolaan terjadi pada awal sesi konseling, pada situasi ini konselor menciptakan hubungan yang baik dengan subjek, dan memberikan pemahaman bagaimana menggunakan komunikasi asertif selama proses konseling. Pada sesi ini subjek lebih sering mengumpat tentang apa yang terjadi pada dirinya, dia menganggap hal ini terjadi karena dia tidak mampu mengendalikan hawa nafsu, emosi dan tidak bisa berjauhan dengan suami.

Hal yang dilakukan :

Melakukan pendekatan secara personal kemudian bersama-sama melakukan latihan komunikasi asertif dan pemberian tips meredakan emosi rasa bersalah, pengendalian hawa nafsu dengan cara mengalihkan pada kegiatan positif lainnya seperti ikut pengajian ataupun ikut club olahraga. Konselor memberikan buku catatan harian yang harus diisi subjek setiap hari.

Hasil :

Setelah jeda waktu Selama 7 hari subjek dan konselor mempunyai hubungan yang baik sehingga konselor dengan mudah dapat menggali permasalahan yang dihadapi subjek, subjek mulai bisa menggunakan komunikasi yang asertif dan mulai bisa mengendalikan emosi. Subjek juga telah mengikuti club olahraga sehingga ia merasa lebih sehat dan bahagia.

Di akhir setiap sesi peretemuan konselor memberikan motivasi bahwa segala kondisi krisis bukan hanya menyebabkan peluang menjadikan keadaan semakin memburuk, melainkan juga dapat memberikan peluang peningkatan pembelajaran pendewasaan diri. Konselor menyampaikan kepada subjek bahwa ia mempunyai kesempatan untuk berkembang menjadi lebih baik.

Konselor dan subjek juga sudah menyepakati jadwal sesi konseling selanjutnya.

2. Fase II, pengawasan yaitu usaha konselor agar subjek mampu mengikuti prosedur konseling, rajin menulis di buku harian.

Hal yang dilakukan :

\footnotetext{
* Dina Fariza Tryani Syarif, M.Psi Dosen FKIP Universitas Muhammadiyah Palangkaraya
} 
Cara pengawasan adalah konselor untuk melakukan pengamatan hal ini mendatangi rumah subjek di luar waktu dilakukan untuk memastikan subjek telah konseling dengan tujuan mengetahui pola melakukan kegiatan-kegiatan positif apabila kehidupan subjek sebenarnya, dan melakukan pengecekan apakah subjek melakukan beberapa hal yang telah disepakati pada pertemuan sebelumnya. Sesekali pada kahir pekan konselor juga ikut pergi olahraga dengan subjek, selain suaminya tidak bisa datang ke Palangka Raya untuk menemuinya. Pada pertemuan di fase II konselor juga mengajak subjek untuk dapat melakukan perbandingan positif-negative dari aktivitas yang dapat memicunya berselingkuh.

\begin{tabular}{|c|c|c|}
\hline $\begin{array}{l}\text { "jika saya tetap mencari laki-laki } \\
\text { yang mau berselingkuh dengan } \\
\text { saya" }\end{array}$ & $\begin{array}{|lc|}\text { "jika saya } & \text { mulai } \\
\text { mengurangi } & \\
\text { berselingkuh } & \text { dengan } \\
\text { laki-laki lain" } & \end{array}$ & $\begin{array}{lrr}\text { "jika saya } & \text { berhenti } & \text { mencari } \\
\text { laki-laki } & \text { yang } & \text { mau } \\
\text { berselingkuh } & \text { dan } & \text { berhenti } \\
\text { berselingkuh } & \text { dari } & \text { suami } \\
\text { saya" } & & \\
\end{array}$ \\
\hline $\begin{array}{l}\text { a. Apa hal baik jika saya } \\
\text { mempertahankan prilaku ini? } \\
\text { "Hahahahaha...mana ada hal } \\
\text { baiknya mbak...paling juga } \\
\text { saya dapat kesenangan sesaat } \\
\text { iyakan mbak?" }\end{array}$ & \begin{tabular}{|l} 
a. Apa hal baik jika \\
saya \\
mempertahankan \\
prilaku ini? \\
"Hmmm...saya \\
bisa stress \\
mbak..hahaha \\
bercanda...saya \\
bisa mulai belajar \\
memperhatikan \\
suami tanpa ada \\
kepalsuan mbak."
\end{tabular} & $\begin{array}{l}\text { a. Apa hal baik jika saya } \\
\text { mempertahankan } \\
\text { prilaku ini? } \\
\text { "Yang pertama saya } \\
\text { sudah tidak lagi berdosa } \\
\text { mbak, kedua hidup saya } \\
\text { lebih tenang tidak was- } \\
\text { was terus, saya lebih } \\
\text { bisa menghargai suami } \\
\text { dan bahkan diri saya } \\
\text { mbak." }\end{array}$ \\
\hline $\begin{array}{l}\text { b. Apa hal buruk jika saya } \\
\text { mempertahankan prilaku ini? } \\
\text { "Ya banyak mbak... saya bisa } \\
\text { saja ketahuan sama suami, sama } \\
\text { keluarga terus membuat nama } \\
\text { baik keluarga menjadi hancur, } \\
\text { saya diceraikan suami, atau saya } \\
\text { kena penyakit kelamin yang } \\
\text { akhirnya membuat saya menjadi } \\
\text { mandul nggak punya anak, } \\
\text { hidup saya terus was-was." }\end{array}$ & $\begin{array}{l}\text { b. Apa hal buruk jika } \\
\text { saya } \\
\text { mempertahankan } \\
\text { prilaku ini? } \\
\text { "Ya saya bisa } \\
\text { kebablasan mbak, } \\
\text { bisa aja saya malah } \\
\text { hamil dengan laki- } \\
\text { laki lain bukan } \\
\text { dengan suami } \\
\text { saya." }\end{array}$ & $\begin{array}{l}\text { b.Apa hal buruk jika saya } \\
\text { mempertahankan prilaku } \\
\text { ini? } \\
\text { "Saya pasti merasa } \\
\text { kesepian mbak tanpa } \\
\text { teman, sedangkan suami } \\
\text { saya jauh dan kurang } \\
\text { perhatian kepada saya." }\end{array}$ \\
\hline
\end{tabular}

Hasil :

Subjek sudah mulai mengisi hari-harinya dengan kegiatan positif dan rajin mengisi buku harian yang telah diberikan konselor, dan ketika rasa kesepian datang ia mengisinya dengan pergi jalan-jalan dengan teman wanita atau pergi menghabiskan waktu untuk berolahraga.

Subjek sudah mulai bisa memetakan hal positif dan negatif yang terjadi pada dirinya dengan kesadarannya sendiri dia bisa memahami apa saja hal positif dan negatif 
yang terjadi pada dirinya apabila dia tetap mempertahankankan prilaku selingkuhnya.

Konselor mengapresiasi semua perubahan yang dialami oleh subjek dan mempertahankan semua perkembangan yang sudah dicapai subjek. Konselor juga memberi saran agar subjek mulai mengurangi frekuensi untuk bertemu dengan pasangan selingkuh, dan apabila dirasa sulit oleh subjek, subjek harus kembali menguatkan dirinya agar bisa menjadi lebih baik.

Pertemuan ke II di fase II konselor mengajari subjek cara self care agar subjek lebih dapat menghargai dirinya sebagai seorang perempuan yang terhormat. Dikarenakan subjek mengakui kepada konselor bahwa dia masih saja bertemu dengan pasangan selingkuhnya, walaupun intensitasnya mulai berkurang karena dia sudah mulai sibuk dengan berbagai kegiatan, dan suami pun lebih perhatian dengan subjek. Kemudian konselor mengajari subjek untuk melakukan tiga tahapan self care agar subjek dapat mempertahankan perawatan diri yang merupakan sumber kekuatan yang dapat membantunya dalam pemulihan diri. 3 bentuk perawatan diri yang dibahas adalah secara fisik, sosial dan spiritual. Konselor bertanya dengan subjek kira-kira yang terbayang oleh subjek apa saja self care yang telah dilakukannya selama ini, subjek mengatakan "makan sehat 3 kali sehari, ngobrol dengan teman-teman membahas tentang model gaya terbaru, ikut orang tua ke pengajian". Dari jawaban subjek konselor mengetahui bahwa sebenarnya subjek telah memahami prinsip dasar self care, kemudian mulai mendiskusikan alternatif self care yang dapat dilakukan oleh subjek :

a. Self care secara fisik

Subjek dapat mengusahakan istirahat cukup setiap harinya, pergi berolahraga sesuai dengan hobby subjek, pergi ke salon untuk dapat melakukan perawatan diri.

b. Self care secara sosial

Konselor menyarankan kepada subjek untuk dapat melanjutkan hobby menulis blognya, konselor menyarankan mungkin bisa mengganti topik tulisan di blog tidak tentang kisah percintaan tetapi melakinkan tentang tata busana, atau cara menggunakan make-up, atau penggunaan hijab yang modis sesuai dengan hobby subjek. Terlintas dalam diri subjek suatu saat ia ingin punya butik sekaligus salon agar dia dapat menyalurkan hobbynya. Konselorpun memberikan semangat kepada subjek agar suatu saat dapat mewujudkan keinginannya itu, dan mencari peluang kerjasama dengan pihak lain agar dapat mewujudkan mimpinya.

c. Self care secara spiritual

Konselor menyarankan kepada subjek agar lebih sering ntuk mengikuti pengajian, atau pergi ke acara workshop atau seminar keagamaan agar dapat mendapatkan kesejukan batin dan pengetahuan agama.

Konselor juga mengajarkan subjek cara penenangan diri dengan trik relaksasi pernafasan yang bisa dilakukan apabila subjek dalam kondisi yang kurang nyaman atau sedang sedih.

Di akhir sesi diskusi konselor juga menyarankan kepada subjek untuk lebih banyak bercerita tentang kegundahan hatinya kepada sahabat wanita atau langsung saja bercerita kepada suami daripada ia harus mencari teman laki-laki untuk mengobrol dan bercerita. Dan mengajaknya berpikir dampak positif

\footnotetext{
* Dina Fariza Tryani Syarif, M.Psi Dosen FKIP Universitas Muhammadiyah Palangkaraya
} 
dan negatif apabila dia bercerita kepada orang lain tentang permasalahan dirinya.

Hasilnya :

Subjek lebih mamahami langkahlangkah merawat dirinya agar dia lebih kuat untuk mencapai perkembangan ke arah lebih baik, karena jauh di dalam diri subjek ia sebenarnya merasa bersalah, berdosa dan lelah dengan semua keadaan dirinya.

3. Fase ke III

Pada fase ini subjek diajak untuk lebih dapat melakukan penelian fungsi diri dan melakukan perubahan diri atau moving on .

Konselor mengajak subjek untuk dapat membuat penilaian keberfungsian diri, dan mampu menilai kekuatan dan kelemahan dirinya.

Hal yang dilakukan :

Penilaian fungsi pernikahan, interaksi hubungan pernikahan guna membantu subjek memahami mengapa terjadi perselingkuhan.

Hasil :

\begin{tabular}{|c|c|}
\hline Kekuatan subjek & Kelemahan subjek \\
\hline $\begin{array}{l}\text { a. Mudah bergaul, hingga mempunyai } \\
\text { banyak teman } \\
\text { b. Energik, hingga lebih menyenangi } \\
\text { beraktifitas di luar rumah } \\
\text { c. Mandiri, lebih sering menyelesaikan } \\
\text { permasalahan yang dihadapinya sendiri. } \\
\text { d. Pandai bertutur kata. }\end{array}$ & $\begin{array}{l}\text { a. Mudah merasa kesepian } \\
\text { b. Mudah tergoda atas rayuan } \\
\text { orang lain } \\
\text { c. Selalu ingin diperhatikan } \\
\text { d. Mudah tersinggung dan mudah } \\
\text { marah }\end{array}$ \\
\hline
\end{tabular}

Konselor memberikan tugas kepada subjek untuk dapat sebanyak-banyaknya mengetahui apa saja yang merupakan kekuatan dirinya dan kelemahan dirinya dan berpikir kembali untuk bagaimana mengatasi kelemahan dan menggunakan kekuatan yang dimilikinya. Seperti mengatasi rasa mudah kesepian yaitu dengan salah satu cara adalah berkumpul dengn teman-temannya semasa sekolah dulu yang mempunyai hobby sama atau menyibukkan diri dengan browsing model busana terbaru kemudian belajar merancang busana sendiri. Karena hanya subjeklah yang mampu mengatasi kelemhan yang ada di dalam dirinya, konselor hanya memberikan saran dan penguatan terhadap dirinya.

Kemudian konselor mengajak subjek untuk melakukan pemaafan atau moving on terhadap dirinya sendiri, karena apa yang terjadi pada diri subjek dikarenakan rasa bersalah terhadap dirinya yang sudah berlebihan sehingga ia akan terus melakukan kesalahan yang sama karena sudah terlanjur berbuat salah, baginya dengan melakukan perselingkuhan lagi akan mengurangi rasa bersalahnya terhadap dirinya, karena dia bisa melupakan sejenak ketika sedang asyik dengan pasangannya. Pada sesi ini konselor menyampaikan kepada subjek bahwa subjek tidak perlu langsung mengambil keputusan untuk mampu melakukan pemaafan terhadap dirinya sendiri atau tidak. Pada sesi ini lebih pada agar subjek dapat memahami apa sebenarnya yang terjadi pada dirinya, apakah prilaku yang terus terulang bisa membuatnya layak untuk dimaafkan, apabila hal itu sudah dipahami subjek 
barulah ia dapat mempertimbangkan apakah sudah saatnya pada mencapai tahap memaafkan atau hanya menerima saja apa yang terjadi.

a. Tahap pertama konselor menanyakan kepada subjek apa definisi pemaafan yang dikatahuinya. Subjek mengatakan memaafkan adalah "memahami apa yang telah saya lakukan terhadap diri saya dan membuatnya semakin jelas sehingga saya benar-benar tahu mana saja kesalahan saya yang tidak pantas terulang" konselor kemudian menambahkan pemahan subjek tentang pemaafan diri sendiri adalah ketika kita sudah dapat meningkatkan pemahan tentang diri, orang lain, dan hubungan kehidupan sehingga orang tersebut tidak lagi didominasi emosi perilaku negatif. Ada 3 komponen memaafkan : realistis, tidak didominasi oleh perilaku negatif dan berkurang hasrat untuk menghukum diri sendiri ataupun orang lain. Selanjutnya pada sesi ini lebih banyak berdiskusi tentang berbagai mitos pemaafan, apakah sebuah pemaafan keuntungan bagi kehidupan subjek.

Setelah sesi diskusi berakhir konselor memberikan pemahaman kepada subjek bahwa subjek sekarang sebaiknya berfokus pada pemulihan diri sendiri, daripada terus memikirkan orang lain yang belum tentu akan dapat terus bersama dengan subjek. Kemudian konselor juga menjeleskan di semua sesi-sesi pertemuan konseling merupakan bagian dari sebuah pemaafan dimana subjek bisa lebih memahami alasan-alasan terjadinya kasus ini, sehingga subjek dapat mengulangi dan mengeksplorasi setiap pengalaman yang dialami dan memberikan pemaknaan baru pada pengalaman yang dialaminya. Apabila hal tersebut adalah pengalaman yang kurang menyenangkan, maka sebaiknya subjek melihat hal tersebut sebagai suatu proses belajar daripada subjek terus menerus menyesali keadaan. Namun ketika subjek telah berusaha namun gagal untuk memaafkan dirinya, konselor menganjurkan kepada subjek untuk berfokus pada tahapan penerimaan dan moving on, yaitu menerima secara intelektual (paham apa yang terjadi), meneriam secara emosional (paham apa yang dirasakan dan mampu mengendalikan emosi negatif) dan berfokus pada harapan dan cita-cita yang lebih baik.

Hasil :

Subjek mengetahui dan memahami konsep memaafkan secara lebih mendalam. Hal ini juga dapat menambah pengetahuan subjek dari seorang ustadzah yang sering mengisi pengajian yang dihadiri oleh subjek.

Subjek Setelah mengikuti sesi-sesi konseling subjek lebih dapat memahami apa yang sebenarnya terjadi di dirinya, dia tersadar bahwa selama ini dia hidup di bawah khayalannya, bahwa kesenangan yang dirasakannya selama ini hanya sesaat hanya untuk mengobati rasa bersalah yang dialami oleh subjek yang telah melanggar janji terhadap dirinya dan suaminya.

Konselor memberikan penguatan bahwa sekecil apapun peningkatan yang terjadi pada diri subjek harus tetap dihargai, yakinlah akan ketangguhan diri yang dimiliki oleh diri kita sendiri.

\section{Fase ke IV}

Fase ini subjek harus memiliki kepribadiann yang integral sebagai manusia sebagai kesatuan secara 
menyeluruh, pada fase ini diketahui bahwa :

Bagi subjek keikutsertaannya dalam intervensi ini sangat bermanfaat. Menurutnya hal utama yang dapat ia pelajari dari intervensi ini adalah bagaimana berfikir dapat mempengaruhi perasaan dan sebaliknya perasaan dapat mempengaruhi cara berfikir baginya. Subjek juga terlatih untuk mengidentifikasi fikiran yang dimilikinya, sehingga ia sadar akan asal dari perasaan dan prilakunya. Dalam kondisi emosi negatif, iapun sadar memutuskan untuk mengambil keputusan yang terbaik mengatasi permasalahan yang dihadapinya dengan melakukan hal-hal positif. Selama proses intervensi ini subjek merasa dapat menceritakan masalah yang dihadapinya tanpa mendapat penilaian dan merasakan didengarkan. Kemajuan yang dirasakan subjek adalah ia seperti mendapatkan sahabat baru yang dapat mendengarkan permasalahan yang dihadapinya. Subjek mulai menyadari untuk fokus terhadap hal-hal positif yang disukainya, dengan demikian ia bisa memanfaatkan waktunya dengan baik. Dia lebih dapat menghargai dirinya sendiri dengan begitu ia juga menjadi lebih memperhatikan suaminya, dan akhirnya suaminya pun secara perlahan berubah menjadi lebih perhatian dan romantis terhadap dirinya. Dan akhir-akhir ini subjekpun mulai dapat mengabaikan ajakan dari pria selingkuhannya, jika hasrat itu kembali datang subjek biasanya membuka kembali buku harian yang telah dia tulis selama konseling, dari situ ia menyadari lebih banyak pengaruh negatif dibandingkan positif selama ini.
Dari semua sesi konseling yang terberat bagi subjek adalah ketika dia harus mampu memahami arti dari pemaafan yang telah dilakukannya kepada dirinya, dia harus bisa mengalahkan ego dirinya, tetapi karena posisi hubungan dia dan konselor sudah seperti teman dia merasakan cukup nyaman untuk kapanpun bercerita dengan konselor, untuk mengingat kembali tahapan-tahapan konseling. Terlebih lagi proses konseling sempat terpotong selama 2 bulan karena subjek mengikuti kursus kecantikan di Jakarta, hal ini dikarenakan subjek ingin dapat mewujudkan mimpinya. Sehingga pada saat jeda konseling hanya dilakukan via BBM atau telepon, itupun dikarenakan pasangan selingkuh subjek ingin menyusul dirinya ke Jakarta.

Berdasarkan hasil diskusi dengan subjek, subjek mengungkapkan ada faktor internal dan eksternal yang juga mengakibatkan berhasilnya proses konseling :

1. Faktor internal :

a. Motivasi yang besar yang ada di dalam diri subjek untuk dapat menjadi istri yang sempurna untuk suaminya.

b. Motivasi yang besar dalam dirinya untuk dapat berhenti dari kebiasaan buruk yang tentunya penuh dengan dosa, ia menyadari sudah saatnya dirinya untuk bertaubat dan menjadi wanita sholehah.

2. Faktor eksternal :

a. Kesabaran dari konselor yang bersedia menjadi sahabat subjek dan mau mendengarkan subjek tanpa memberikan penilaian buruk terhadap dirinya;

b. Hubungan yang baik antara subjek dan konselor sehingga subjek mudah menghubungi konselor kapanpun, dan 
konselorpun bersedia untuk meluangkan waktunya untuk subjek.

c. Dukungan dari sahabat-sahabat subjek yang juga punya keinginan agar subjek dapat bebas dari kebiasaan buruk hidupnya.

Subjek juga mengatakan sebelum mengikuti sesi konseling secara perilaku ia sering marah secara tiba-tiba, malas berinteraksi dengan keluarga suami, salah tingkah apabila suami memegang handphone subjek, secara kognitif ia merasa sulit berpikir jernih, sering menyalahkan diri sendiri, ingin menjauh dari keluarga suami. Secara emosi yang dialami subjek mudah marah, mudah tersinggung, sering merasa sedih karena sendirian dan secara fisik terkadang sulit tidur dan tidak nafsu makan.

Namun setelah sesi konseling secara prilaku ia sudah mulai membuka diri dengan keluarga suami dengan cara mulai sering mendatangi acara-acara keluarga suami dengan atau tanpa didampingi oleh suami, secara kognitif ia lebih mampu berpikir secara rasional, berpikir positif tidak lagi menyalahkan diri sendiri atas permasalahan ini, secara emosi pun subjek sudah mulai dapat mengendalikan emosi marahnya, tidak lagi merasa sendiri karena sudah mulai banyak mengikuti kegiatan di luar, tidurpun mulai nyenyak dan makan sudah mulai teratur.

\section{PEMBAHASAN}

Hasil penelitian menunjukan proses konseling yang menggunakan pendekatan gestalt yang menekankan pada peran persaaan dalam mempengaruhi prilaku dan potensi manusia untuk mampu memahami dan mengarahkan dirinya sendiri. Kesadaran dipandang sebagai suatu kondisi yang esensial dalam memunculkan kemampuan individu untuk memecahkan berbagai kesulitan yang dialaminya. Teori gestalt menganggap bahwa setiap individu memiliki kemampuan untuk menerima tanggung jawab pribadi, memiliki dorongan untuk mengembangkan kesadaran yang menuju terbentuknya integritas atau keutuhan pribadi (Subandi, 2005), hal ini lah yang dilakukan dalam proses konseling. Semua kejadian dikembalikan kepada diri subjek, meyakinkan bahwa subjek memiliki kemampuan untuk mengatasi permasalahannya, hanya saja semua hal harus disadari oleh diri subjek agar ia mampu secara sadar melakukan perubahan untuk dirinya sendiri. Selain itu keberhasilan intervensi juga dikarenakan adanya keinginan yang kuat dari dalam diri subjek untuk merubah dirinya, motivasi internal yang dimiliki subjek membuatnya menampilkan sikap pro-aktif terhadap intervensi yang dilakukan, kepatuhan subjek mengerjakan pekerjaan rumahnya (mengisi buku harian), dan ia juga menerapkan berbagai materi yang didapatkannya di dalam kehidupan sehariharinya. Hal ini dapat membantu percepatan pemulihan diri dari subjek seperti yang dikatakan Davis dan Piercy dalam Bell, 2009 apabila subjek berkontribusi penuh dan memiliki motivasi internal yang tinggi akan semakin mempercepat masa pemulihan. Selain itu, hal yang membuat keberhasilan dari intervensi ini adalah adanya hubungan yang baik antara subjek dan konselor (rapport), hubungan yang baik antara konselor dan subjek dapat menumbuhkan rasa percaya diri dalam diri subjek untuk dapat memahami permasalahan apa yang sedang dihadapinya dan menemukan penyelesaian dari permasalahan yang dihadapinya. Hal ini sejalan dengan pendapat Davis dan Piercy dalam Bell, 2009 bahwa dengan adanya rapport yang baik akan menumbuhkan rasa 
percaya diri subjek dan membuatnya merasa nyaman untuk menceritakan latar belakang permasalahan yang dihadapinya kepada konselor.

Dari seluruh sesi intervensi yang diberikan terdapat berbagai situasi yang sulit bagi konselor, yaitu mengenai pergeseran asumsi dasar mengenai kesetiaan dalam perkawinan, eksplorasi konterks dan penarikan makna dari sebuah kesetiaan. Pembahasan secara mendalam tentang asumsi kesetiaan, eksplorasi dan penarikan makna dapat memberikan pemahaman yang menyeluruh mengenai kesetiaan dan pengaruh positif dalam jangka panjang untuk pemulihan subjek. pada pelaksanaannya konselor hanya mengidentifikasi dari pemaknaan sebuah kesetiaan dalam konteks hubungan interpersonal, namun tidak melakukan restrukturisasi terhadap pergesaran asumsi secara irrasional, hal ini terjadi karena kesulitan konselor untuk melakukan restrukturisasi serta karena keterbatasan waktu selama sesi-sesi internvensi.

\section{SIMPULAN}

Hasil penelitian ini menunjukan bahwa penerapan intervensi dengan menggunakan metode gestalt dapat dikatakan berhasil. Keberhasilan proses intervensi ini dikarenakan beberapa hal antara lain :

1. Adanya motivasi internal dari dalam diri subjek

2. Adanya hubungan yang baik antara subjek dan konselor

3. Penerapan subjek terhadap materi yang diberikan kepadanya selama sesi konseling, sehingga terjadinya perubahan pada aspek prilaku, kognitif dan emosi pada diri subjek.

\section{DAFTAR PUSTAKA}

Amato,P. R., Booth, A., Johson, D.R.,\& Rogers, S.J. 2009. Alone Together: How Marriage in America is Changing. Cambridge: Harvard University Press.

Aqmalia \& Fakhrurrozi. 2009. Kepuasan Pernikahan pada Pekerja Seks Komersil (PSK)http://www.gundarma.ac.id/library/articles/graduate/psychology/2009/Artikel_1 050314.pdf 9 Juni 2014

Bell, S.K. 2009. A Critical Review of Couple Therapy Models that Address Infidently : Inditifing Common Thems and Introducing A multimodal Intergrative Approach. Proquest Dissertation and Thesis.

Corey, G. 2005. Teori dan Praktek Konseling dan Psikoterapi. Bandung: PT. Eresco

Ekomadyo, A. S. 2006. Prospek Penerapan Metode Analisis Isi (Content Alalysis) dalam Penilitian Media Arsitektur. Jurnal Ilmu Pengetahuan Teknologi dan Seni. Agustus, 10 (2): 51-57

Feist, J.\& Feist, G, J. 2008. Theories of Personality. Yogyakarta: Pustaka Pelajar

Ginanjar, A.S. 2009. Proses healing pada Istri yang mengalami Perselingkuhan Suami. Makara, Sosial Humaniora. Juli, 13 (1): 66-76

Glass, S.P.\&Staeheli, J.C. 2003. Not "just friends" Rebuilding Trust and Recovering Your Sanity After Infidelity. New York: Fee Press.

Gottman, J.,\&Silver, N. 2007. The Seven Principles for Making Marrieage Work. London: Orion Books Ltd.

Hall, C. S.\& Lindzey, G. 2006. Teori-teori Holistik (Organismik-Fenomenologis). Yogyakarta: Kanisius

Harsanti, I. 2008. Motivasi Seorang Wanita untuk melakukan Perselingkuhan. http://www.gundarma.ac.id/library/articles/graduate/psychology/2008/Art ikel_10500380.pdf. 12 Juni 2014.

\footnotetext{
* Dina Fariza Tryani Syarif, M.Psi Dosen FKIP Universitas Muhammadiyah Palangkaraya
} 
Pedagogik Jurnal Pendidikan, Maret 2015, Volume 10 Nomor 1, (9-23)

Hargave, T.D. 2008. Forgiveness Reconciliation After Infidelity. Family Therapy Megazine, March/April 30-33.

Hwari, D. 2004. Love Affair (Perselingkuhan) Prevensi dan Solusi. Jakarta: Balai Penerbit FKUI.

Miles, M. B\&Huberman, A.M. 2006. Analisis Data Kualitatif: Buku Sumber Tentang Metode-metode Baru. Jakarta: UI Press

Moleong, L.J. 2005. Metodologi Penelitian Kualitatif. Bandung: Pt. Remaja Rosdakarya.

Olson,D.H.,\&Defrain, J. 2006. Marriages and Families: Intimacy, Diversity, and Strengths. Fifth Edition. United States: McGrawHill

Pawito. 2007. Penelitian Komunikasi Kualitatif. Yogyakarta: LkiS

Raco, J.R. 2010. Metode Kualitatif: Jenis, karakteristik, dan Keunggulannya. Jakarta

Rimba, L. 2005. Perselingkuhan Wanita Jakarta. KARTINI. 20 Mei 2005.

Satori, D. \& Komariah, A. 2009. Metodologi Penelitian Kualitatif. Bandung: Penerbit Alfabeta.

Semiun, Y. 2006. Teori Kepribadiian dan terapi Psikoanalitik Freud. Yogyakarta; Kanisius

Subandi, M.A. 2002. Psikoterapi : Pendekatan Konvensional dan Kontemporer (Psychotherapy: A Conventional and Contemporary Approaches). Yogyakarta.Penerbit Fakultas Psikologi UGM. Pustaka Pelajar.

Subotonik, R.B.,\&Hariss, G.G. 2005. Surviving Infidelity: Making Decisins, Recovering From The Pain. Avon: Adams Media.

Sudrajat,A.2008.PendekatanKonselingGestalt.http://www.ahmadsudrajat.wordpress.com/2 008/01/23/pendekatan-konseling-gestalt/ 13 Oktober 2014

* Dina Fariza Tryani Syarif, M.Psi Dosen FKIP Universitas Muhammadiyah Palangkaraya 